\title{
Eclipse Impact on a Remote Sensing Data Set: PAL NDVI 10-Day Composite from February 11 to 20 in 1999 for Western Australia
}

\section{Chai K. Lim}

Department of Mathematics and Biostatistics, Walter Reed Army Institute of Research, 503 Robert Grant Ave., Silver Spring, MD 20910, USA; E-Mail: Chai.Lim@US.ARMY.MIL;

Tel.: +1-301-319-7389; Fax: +1-301-319-9285

Received: 30 June 2010; in revised form: 21 July 2010 / Accepted: 16 August 2010 /

Published: 18 August 2010

\begin{abstract}
Pathfinder Normalized Difference Vegetation Index (NDVI) derived from Channel 1 (Red) and Channel 2 (near-infrared) of Advanced Very High Resolution Radiometer (AVHRR) onboard NOAA 14 became abnormally high for the 10-day composite from February 11 to 20 in 1999 for Western Australia. There was a solar eclipse in the satellite path on February 16 about the same time when NOAA 14 was above the eclipse location, causing the Channel 1 value to be 0 in many cells. The NDVI composite updating rule was to capture the greenest condition of each composite period. There seems to have been a possible lack of quality control during the NDVI composite generation, which could have caused the abnormally high NDVI values. However, there were some cells within the affected area that had values close to normal for NDVI as well as Channel 1 and Channel 2. The abnormal NDVI data values could have been avoided by not using the data obtained during the eclipse in the generation of the composite. Further investigation on those cells which were not affected by the eclipse is suggested for a better quality control of remote sensing data obtained during eclipse occurrences.
\end{abstract}

Keywords: NDVI; AVHRR; Eclipse; Western Australia; 10-day composite

\section{Introduction}

About three decades ago, Normalized Difference Vegetation Index (NDVI) derived from NOAA/NASA Pathfinder Advanced Very High Resolution Radiometer (AVHRR) enabled observation of vegetation conditions at global and almost real-time scales unlike any time before. Owing to its 
constant spatial and temporal coverage of Earth's surface, it became feasible to monitor global vegetation development on a relatively continuous and consistent basis. There are numerous examples of how Pathfinder AVHRR Land (PAL) NDVI has been used in various scientific fields such as earth sciences, ecology, climate change, socio-economics, epidemiological studies and more. Pathfinder NDVI has been used to estimate global and regional scale land primary productivity estimates [1,2], identify $\mathrm{CO}_{2}$ fertilization effects in natural settings [3], study vegetation condition and El Niño relationship [4], perform climatic impact modeling for deforestation [5] and epidemiological modeling for tropical diseases such as malaria [6,7].

PAL NDVI data sets were produced in several different temporal and spatial resolutions and cover from July 1981 until September 2001. Before discontinuation, PAL NDVI data sets were publicly available via NASA Goddard Space Flight Center (GSFC) Distributed Active Archive Center (DAAC), which is currently known as Goddard Earth Sciences Data and Information Services Center (GES DISC). At present, more than 20 years of rich Pathfinder NDVI data sets have been archived and removed from public access by the GSFC. Currently available NOAA-AVHRR NDVI data include Global Inventory Modeling and Mapping Studies (GIMMS) monthly NDVI from 1981 to 2002 [8] and Land Long Term Data Record (LTDR) daily NDVI from 1981 to 1999 [9].

Like any other satellite data, Pathfinder NDVI are not perfect. First of all, vegetation indices derived from surface reflectance data such as the Channel 1 (Red) and Channel 2 (near-infrared, NIR) of AVHRR are, in general, not sufficient to fully understand vegetation development because they cannot provide data on green leaf layers under the vegetation surface. Some common imperfection of the data is caused by satellite orbit drift, difference of degradation of the channels 1 and 2 of AVHRR itself and cloud contamination, therefore calibration changes were made throughout the product generations for improvement [10]. Nevertheless, in the case of the second 10-day composite of February 1999 for Western Australia region, AVHRR's observations resulted in PAL NDVI values completely out of the expected range, of which will be investigated in the following sections. The original NASA's 10-day composite image files of PAL NDVI for February 1999 are presented in Appendix A.

\section{Data}

Pathfinder NDVI (noted as 'XVI' in [10]) was derived from two reflectance values; one in red range visible spectrum (Channel 1, wavelength of $0.58-0.68 \mu \mathrm{m}$ ) and the other near-infrared (Channel 2, wavelength of $0.73-1.10 \mu \mathrm{m}$ ) of AVHRR. AVHRR is a passive scanning radiometer, onboard NOAA satellite series. NOAA satellites are near sun-synchronous polar orbiters, and the first satellite that was used to produce Pathfinder NDVI was NOAA-7, which was launched in June 1981. Pathfinder NDVI was defined as NDVI $=\left(R_{2}-R_{1}\right) /\left(R_{1}+R_{2}\right)$, where $R_{1}$ is Channel 1 reflectance and $R_{2}$ is Channel 2, based on the characteristic tendency of green leaves to absorb red radiance, Channel 1, and reflect near-infrared, Channel 2 [11]. That is, more Channel 2 reflectance and less Channel 1 reflectance imply stronger green vegetation signs. The difference of the two channels reflectance was divided by the sum of the two channels to normalize the NDVI to have a range between -1 and 1 .

The publically available $8 \mathrm{~km} \times 8 \mathrm{~km}$ Pathfinder NDVI data sets were provided in two temporal resolutions, 10-day composites and monthly. The AVHRR onboard NOAA, a polar orbiter, could 
provide repetitive measurements of reflectance from the same location during a 10-day composite period owing to its twice daily earth scans with orbital period of 102 minutes and swath of about $2,700 \mathrm{~km}$. The NDVI composites were computed for each cell, and re-computed when new data values became available within the same period [10]. The NDVI value assigned to each cell in the composite image was the highest value for that location during the period of the composite.

In February 1999, the second 10-day composite, a composite of data collected between February 11 and February 20, 1999, of Pathfinder NDVI values for a large number of cells belonging to the Western Australia region were unreasonably high, with the NDVI equal to 1 . The usual expected NDVI would not be greater than 0.3 for most cells of the data set. Figure 1(a) is a time series of Pathfinder NDVI average over the area in Western Australia with longitude range $\left[110^{\circ} \mathrm{E}, 120^{\circ} \mathrm{E}\right]$ and latitude $\left[20^{\circ} \mathrm{S}, 30^{\circ} \mathrm{S}\right]$. Accordingly, the time series of Channel 1 and Channel 2 averages over the same area shows that there was unusually very low reflectance from the area during the same period (Figure 1(b)). What happened?

Figure 1. The Pathfinder 10-day composites averaged over the area with longitude range $\left[110^{\circ} \mathrm{E}, 120^{\circ} \mathrm{E}\right]$ and latitude $\left[20^{\circ} \mathrm{S}, 30^{\circ} \mathrm{S}\right]$ from January 1998 to June 1999 . (a) NDVI, (b) AVHRR Channel 1 and Channel 2 reflectance in percent.

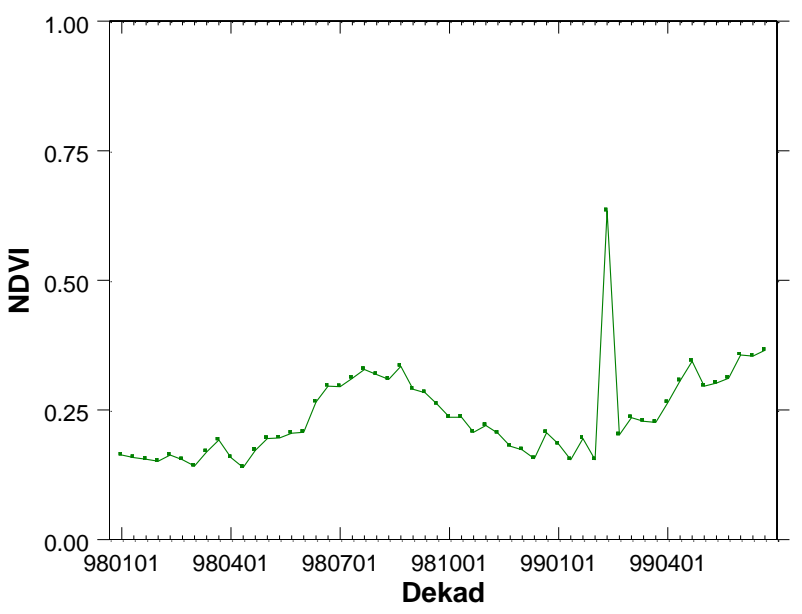

(a)

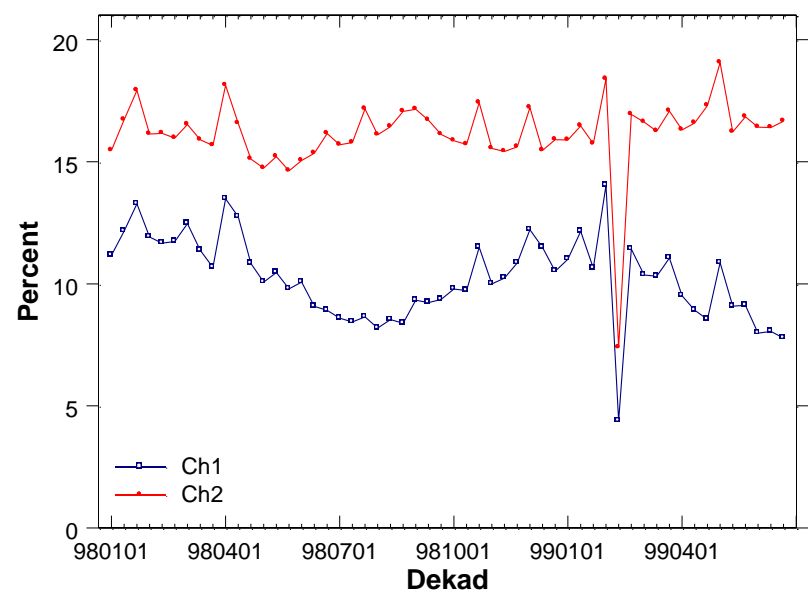

(b) 


\section{Results and Discussion}

On February 16, 1999 between 07:27:20 UTC and 07:35:48 UTC, NOAA 14 was in ascending node covering a geographic region in Western Australia with four corners $[\mathrm{NW}, \mathrm{SW}, \mathrm{SE}, \mathrm{NE}]=\left[\left(15.66^{\circ} \mathrm{S}\right.\right.$, $\left.101.48^{\circ} \mathrm{E}\right),\left(44.7^{\circ} \mathrm{S}, 105.05^{\circ} \mathrm{E}\right),\left(39.17^{\circ} \mathrm{S}, 140.61^{\circ} \mathrm{E}\right),\left(11.43^{\circ} \mathrm{S}, 128.72^{\circ} \mathrm{E}\right)$ ] [12]. Therefore, during that time period, the Western Australia region was in the above quadrilateral, and consequently under NOAA 14's coverage. AVHRR Channel 1 has instantaneous field-of-view (IFOV) 1.39 milliradian and Channel 2 has 1.41. This allows the Channel 1 and Channel 2 detectors to have a ground resolution of approximately $1.17 \mathrm{~km}$ at the NOAA satellite nadir from its nominal orbit altitude of $833 \mathrm{~km}$. Appendix B presents a copy of a foot print data of NOAA 14 from 07:29:53 to 07:32:38 UTC on February 16, 1999, and Appendix C presents the time stamped image data from NOAA 14 passing over the West Australian Coast from 07:29 to 07:32 UTC on February 16, 1999.

Table 1. The center, northern and southern limits of the solar eclipse path between 07:25 UT and 07:40 UT on February 16, 1999.

\begin{tabular}{ccccccc}
\hline \multirow{2}{*}{ UT } & \multicolumn{2}{c}{ Northern Limit } & \multicolumn{2}{c}{ Southern Limit } & \multicolumn{3}{c}{ Center Line } \\
& Latitude $\left({ }^{\circ} \mathbf{S}\right)$ & Longitude $\left({ }^{\circ} \mathbf{E}\right)$ & Latitude $\left({ }^{\circ} \mathbf{S}\right)$ & Longitude $\left({ }^{\circ} \mathbf{E}\right)$ & Latitude $\left({ }^{\circ} \mathbf{S}\right)$ & Longitude $\left({ }^{\circ} \mathbf{E}\right)$ \\
\hline $07: 25$ & 29.650 & 113.383 & 29.892 & 113.690 & 29.770 & 113.537 \\
$07: 30$ & 28.475 & 115.483 & 28.725 & 115.822 & 28.600 & 115.652 \\
$07: 35$ & 27.252 & 117.703 & 27.508 & 118.078 & 27.378 & 117.890 \\
$07: 40$ & 25.967 & 120.085 & 26.233 & 120.505 & 26.100 & 120.293 \\
\hline
\end{tabular}

On the same day, the first solar eclipse of 1999, which was an annular eclipse, began about 1,000 km south of South Africa at 04:57 UTC and headed eastward slightly toward the north. The path of annularity crossed into Western Australia about $300 \mathrm{~km}$ north of Perth at 07:28 UTC with the path width $42 \mathrm{~km}$ and the duration of annularity 48 seconds [13]. Table 1 shows the center, northern and southern limits of the eclipse path between 07:25 UTC and 07:40 UTC. Figure 2 juxtaposes the foot print of NOAA 14 and the eclipse shadow passage over the coastline of Western Australia. The line segment denoted ' 1 ' in Figure 2 presents the instantaneous south boundary of the swath of the Channel 1 and Channel 2 detectors onboard NOAA 14 at 07:27:20 UTC; and '4' the instantaneous north boundary of the swath at 07:35:48 UTC. The line segments denoted ' 2 ' and ' 3 ' are the approximate locations of the ground resolution cells at the given times. In Figure 2 the circles denoted with the letters ' $a$ ' to ' $d$ ' present the center locations of the eclipse antumbral shadow path at the matching time, that is, 'a' at 07:27:20 UTC, 'b' 07:30:00 UTC, 'c' 07:35:00 UTC and 'd' 07:35:48 UTC.

The eclipse path was in the path of NOAA 14 when it was above Western Australia on February 16, 1999. AVHRR is a passive sensor, and the natural source of reflectance, sun light, for the sensor was not available throughout the eclipse antumbral shadow path on that day. Due to the eclipse, the lack of illumination resulted in a radiance for Channel 1 and 2 that was unusually low; and in many cells Channel 1 (visible spectrum) reflectance was " 0 ", which caused NDVI to become " 1 " regardless of what the Channel 2 values were. Table 2 shows a number of cell values of the PAL NDVI 10-day composites for February 1999. Seeing NDVI = 1 in some cells, one might conclude that the high NDVI values were caused by high values of Channel 2 and low Channel 1 , since NDVI $=\left(R_{2}-R_{1}\right) /\left(R_{1}+R_{2}\right)$, where $R_{1}$ is Channel 1 reflectance and $R_{2}$ is Channel 2 reflectance. 
However, those cells with abnormally high NDVI values during the second 10-day composite period had much lower Channel 2 reflectance than the ones in the other two adjacent composites.

Figure 2. Instantaneous boundaries (1: south, 4: north) and approximate locations of ground resolution cells $(2,3)$ for the swath of ascending NOAA 14 at each time in UT; and path of the eclipse antumbra center in the same time order (a: 07:27:20, b: 07:30:00, c: 07:35:00 and d: 07:35:48) on February 16, 1999.

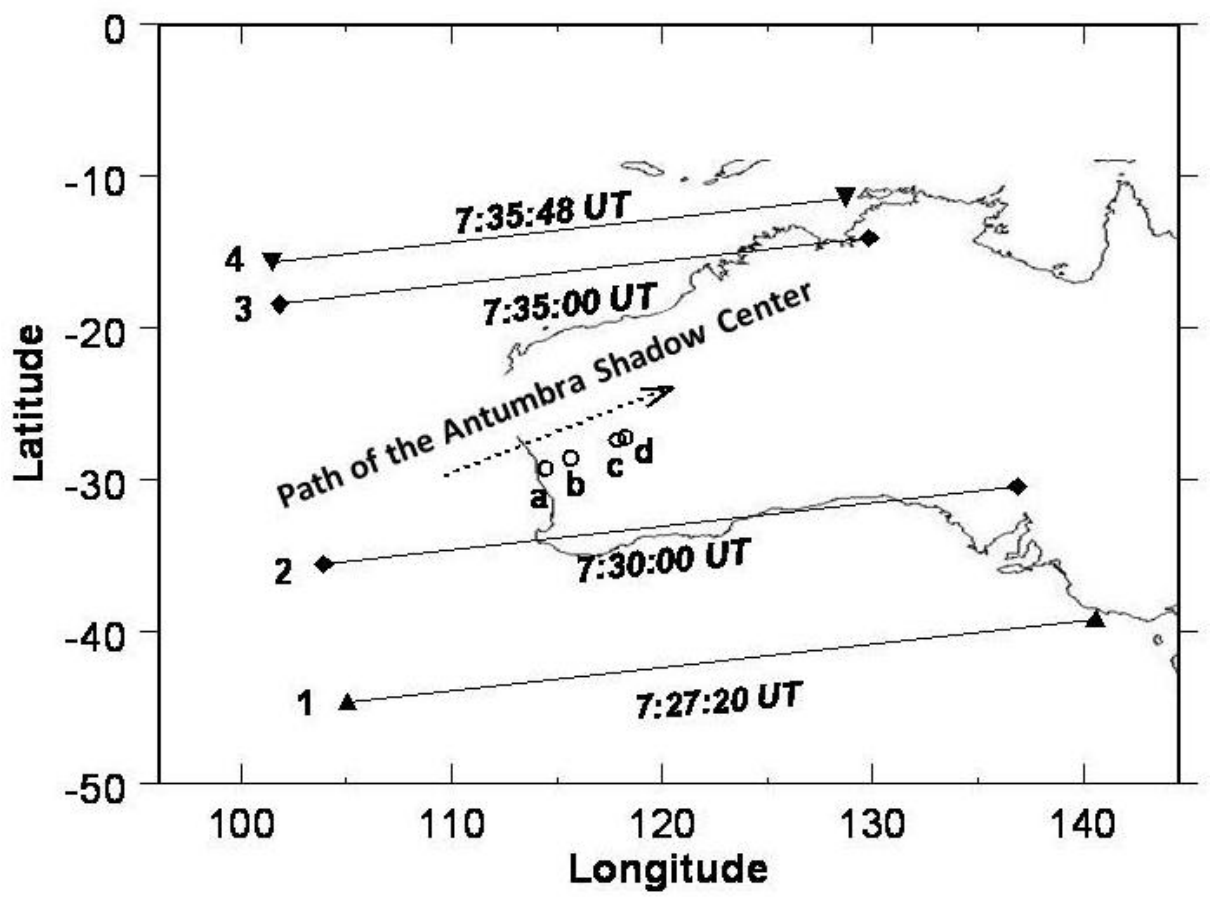

Table 2. A small subset extracted from the original 10-day composites of PAL NDVI, Channel 1 and Channel 2 for February 1999 (19990201: from 1 February to 10, 19990211: 11 to 20 and 19990221: 21 to 28): Shaded values present abnormally high NDVI and corresponding Channel 1 and Channel 2 values.

\begin{tabular}{ccccccccccc}
\hline & & & $\mathbf{1 9 9 9 0 2 0 1}$ & & \multicolumn{3}{c}{$\mathbf{1 9 9 9 0 2 1 1}$} & \multicolumn{3}{c}{$\mathbf{1 9 9 9 0 2 2 1}$} \\
Longitude & Latitude & NDVI & Ch1 & Ch2 & NDVI & Ch1 & Ch2 & NDVI & Ch1 & Ch2 \\
\hline 114.54 & -25.86 & 0.168 & 16.588 & 23.604 & 1 & 0.000 & 0.528 & 0.184 & 11.854 & 17.246 \\
114.62 & -25.86 & 0.192 & 15.134 & 22.332 & 1 & 0.000 & 0.956 & 0.168 & 13.052 & 18.574 \\
114.7 & -25.86 & 0.168 & 18.098 & 25.700 & 1 & 0.000 & 1.174 & 0.152 & 12.626 & 17.314 \\
114.78 & -25.86 & 0.176 & 18.148 & 26.012 & 1 & 0.000 & 1.174 & 0.144 & 11.892 & 16.030 \\
114.86 & -25.86 & 0.144 & 8.974 & 12.136 & 1 & 0.000 & 1.176 & 0.176 & 8.704 & 12.594 \\
$\mathbf{1 1 4 . 9 4}$ & -25.86 & 0.192 & 15.482 & 23.172 & $\mathbf{0 . 2 3 2}$ & 7.656 & $\mathbf{1 2 . 4 3 2}$ & 0.144 & 11.142 & 14.990 \\
$\mathbf{1 1 3 . 0 1}$ & -25.93 & 0.136 & 16.204 & 21.306 & $\mathbf{0 . 1 6 0}$ & $\mathbf{1 0 . 2 8 8}$ & $\mathbf{1 4 . 3 6 2}$ & 0.200 & 8.594 & 12.946 \\
113.09 & -25.93 & 0.152 & 16.000 & 21.756 & 1 & 0.000 & 0.916 & 0.128 & 10.644 & 13.834 \\
113.17 & -25.93 & -0.064 & 37.912 & 33.708 & 1 & 0.000 & 0.488 & -0.064 & 16.880 & 14.874 \\
113.25 & -25.93 & -1.016 & -0.018 & -0.018 & -1.016 & -0.018 & -0.018 & -1.016 & -0.018 & -0.018 \\
113.33 & -25.93 & -1.016 & -0.018 & -0.018 & -1.016 & -0.018 & -0.018 & -1.016 & -0.018 & -0.018 \\
113.41 & -25.93 & -1.016 & -0.018 & -0.018 & -1.016 & -0.018 & -0.018 & -1.016 & -0.018 & -0.018 \\
113.49 & -25.93 & 0.104 & 17.110 & 21.344 & 1 & 0.000 & 1.352 & 0.224 & 9.956 & 15.704 \\
113.57 & -25.93 & 0.160 & 13.154 & 18.424 & 1 & 0.000 & 0.712 & 0.176 & 12.054 & 17.488 \\
\hline
\end{tabular}


The abnormally high NDVI values obtained on February 16, 1999, became the official NDVI 10-day composite values, partially due to a failure of strictly following the 'updating rule' for NDVI composite. Updating of the composites was to be performed cell by cell. The difference of Channel 2 and Channel 1 values for the new data was computed, and compared to the basic composite array. If the new difference was greater, then the NDVI value for the new data point was computed and replaced the previous NDVI [10]. In the case of the second 10-day composite in February 1999, probably not $\left(R_{2}-R_{1}\right)$, where $R_{1}$ is Channel 1 reflectance and $R_{2}$ is Channel 2 reflectance, was compared but the NDVI itself, $\left(R_{2}-R_{1}\right) /\left(R_{1}+R_{2}\right)$, was compared to select greater NDVI for a cell and caused such abnormality in the values. The abnormality of the NDVI 10-day composite from February 11 to 20 is more clearly shown in Figure 3 for a small portion of the affected area close to Shark Bay in Western Australia. Figure $3 \mathrm{~b}$ is the surface greenness plotted according to the NDVI second 10-day composite in February 1999, which shows an abrupt increase of the greenness from the previous 10-day composite, (a), then an abrupt decrease to the following, (c).

Figure 3. Pathfinder NDVI in $8 \mathrm{~km} \times 8 \mathrm{~km}$ resolution (approximately $0.8^{\circ}$ Lon $\times$ $0.723^{\circ}$ Lat) for the first, (a), second, (b) and last, (c) 10-day composites of February in 1999. The quadrilateral covers longitude range $\left[113^{\circ} \mathrm{E}, 115^{\circ} \mathrm{E}\right]$ and latitude $\left[25^{\circ} \mathrm{S}, 27^{\circ} \mathrm{S}\right]$. The city locations shown in the plot (a) are approximate.

(a)

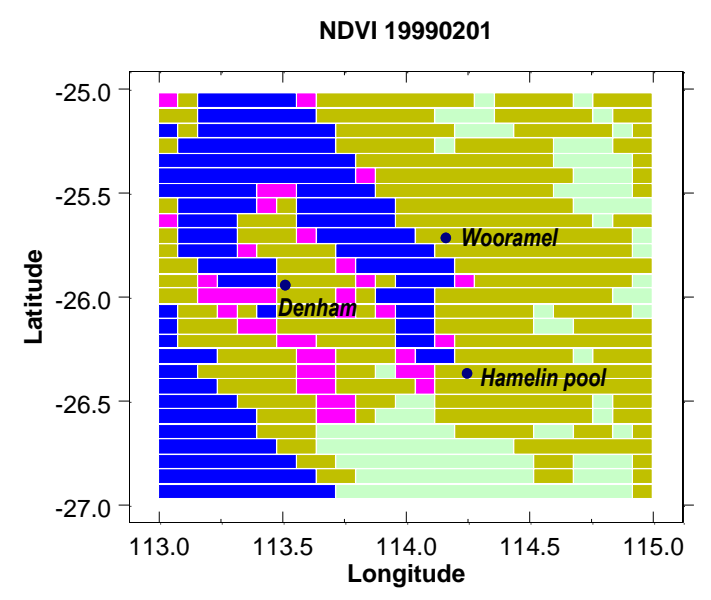

(c)

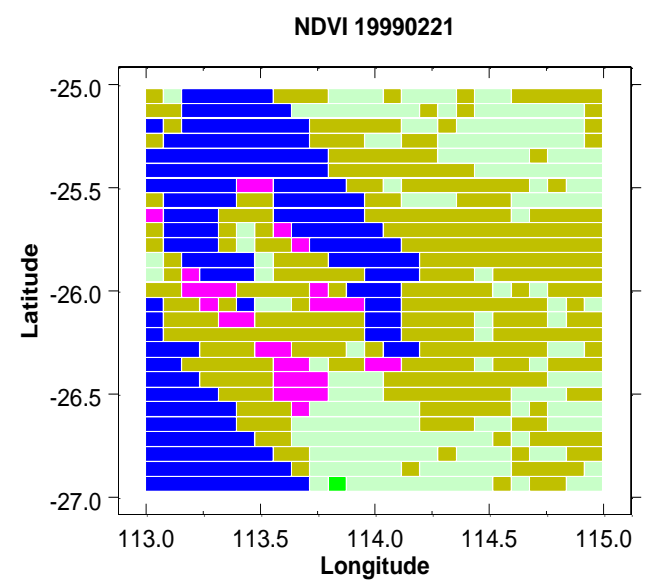

(b)

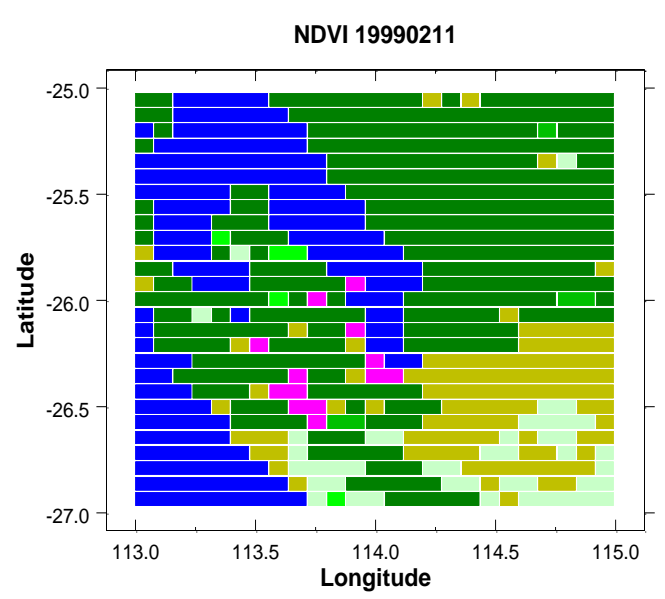


During the eclipse there were some cells of which reflectance in Channel 1 and Channel 2 were close to normal such as the cells with bolded, italicized text in Table 2. It is not clear why those cells were not affected by the eclipse. However, possible explanations might be that those cells were somewhat far off eclipse's antumbra at the moment when the sensor was directing to them, and some sun light was allowed, or the pixels were selected from other overpasses that were not under the eclipse condition.

The fact that the PAL NDVI became abnormally high for the 10-day composite from February 11 to 20 in 1999 for Western Australia was due to (1) the solar eclipse occurrence in the satellite path and (2) the NDVI composite updating rule, and (3) possible lack of quality control during the NDVI composite generation. The actual Channel 1 and Channel 2 data values for the composite from February 11 to 20 were not proper data sources for NDVI composite computation for the period. The abnormal data values could have been avoided by simply not using the data obtained during the eclipse in the generation of the composite.

More careful examination of the observed values of the AVHRR channels 1 and 2 during the second 10-day composite period in February 1999 is desired, perhaps with data in a higher spatial and temporal resolution to have a better understanding of eclipse impacts on remotely sensed data. In addition, further investigation on those ground cells not affected by the eclipse is suggested for it can provide valuable insights on how to efficiently screen out irregular data values obtained under an unusual condition such as an eclipse. It will be then possible to explore a range of quality control tests to see which are capable of eliminating the eclipse-affected values to avoid a production of incorrect data.

\section{Acknowledgements}

We would like to thank Soltan M. Malekghassemi at the University of Virginia for aiding to read and grid the data with $\mathrm{C}++$ programming; and Jeffrey Robel at NOAA for a reproduction of the time stamped Earth image from NOAA 14. This paper was initiated when the author was affiliated with George Mason University, VA, U.S.A. The opinions or assertions contained herein are the private views of the author, and are not to be construed as official, or as reflecting true views of the Department of the Army or the Department of Defense.

\section{References}

1. Prince, S.D.; Goward, S.N. Global primary production: A remote sensing approach. J. Biogeogr. 1995, 22, 815-835.

2. Goward, S.N.; Dye, D.G. Evaluating North American net primary productivity with satellite observations. Adv. Space Res. 1987, 7, 165-174.

3. Lim, C.; Kafatos, M.; Megonigal, P. Correlation between atmospheric CO2 concentration and vegetation greenness in North America: CO2 fertilization effect. Climate Res. 2004, 28, 11-22.

4. Lim, C.; Kafatos, M. Frequency analysis of natural vegetation distribution using NDVI/AVHRR data from 1981 to 2000 for North America: Correlations with SOI. Int. J. Remote Sens. 2002, 23, 3347-3383. 
5. Welch, R.M.; Ray, D.K.; Nair, U.S.; Sever, T.; Irwin, D. Impact of deforestation on the proposed Mesoamerican biological corridor in Central America. In Proceedings of 19th Conference on Hydrology, 85th AMS Annual Meeting, San Diego, CA, USA, January 2005.

6. Gemperli, A.; Vounatsou, P.; Sogoba, N.; Smith, T. Malaria mapping using transmission models: Application to survey data from Mali. Amer. J. Epidemiol. 2006, 163, 289-297.

7. Thomson, M.C.; Connor, S.J.; D’Alessandro, U.; Rowlingson, B.; Diggle, P.; Cresswell, M.; Greenwood, B. Predicting malaria infection in Gambian children from satellite data and bed net use surveys: The importance of spatial correlation in the interpretation of results. Amer. J. Trop. Med. Hyg. 1999, 61, 2-8.

8. Global Inventory Modeling and Mapping Studies (GIMMS) Product Guide; Global Land Cover Facility, University of Maryland: College Park, MD, USA, 2010. Available online: http://glcf.umiacs.umd.edu/data/gimms/description.shtml (accessed on August 17, 2010).

9. Land Long Term Data Record, Data Products; NASA: Greenbelt, MD, USA, 2010. Available online: http://ltdr.nascom.nasa.gov/cgi-bin/ltdr/ltdrPage.cgi?fileName=products (accessed on August 17, 2010).

10. Kidwell, K.B. Global Vegetation Index User's Guide; National Oceanic and Atmospheric Administration: Washington, DC, USA, 1994.

11. Tucker, C.J. Red and photographic infrared linear combinations for monitoring vegetation. Remote Sens. Environ. 1979, 8, 127-150.

12. Comprehensive Large-Array data Stewardship System; NOAA Satellite and Information Service: Silver Spring, MD, USA, 2009. Available online: http://www.class.ncdc.noaa.gov/saa/ products/welcome;jsessionid=32FA0CAB1DDB252BF590C230D33CF1A2 (accessed on December 17, 2009).

13. Espenak, F. Eclipses during 1999, Observer's Handbook 1999; Royal Astronomical Society of Canada: Toronto, ON, Canada, 2004. Available online: http://eclipse.gsfc.nasa.gov/SEmono/ ASE1999/ASE1999.html (accessed on August 17, 2010). 


\section{Appendix}

Appendix A. The original NASA image files of NDVI 10-day composites presented on its website for February 1999.
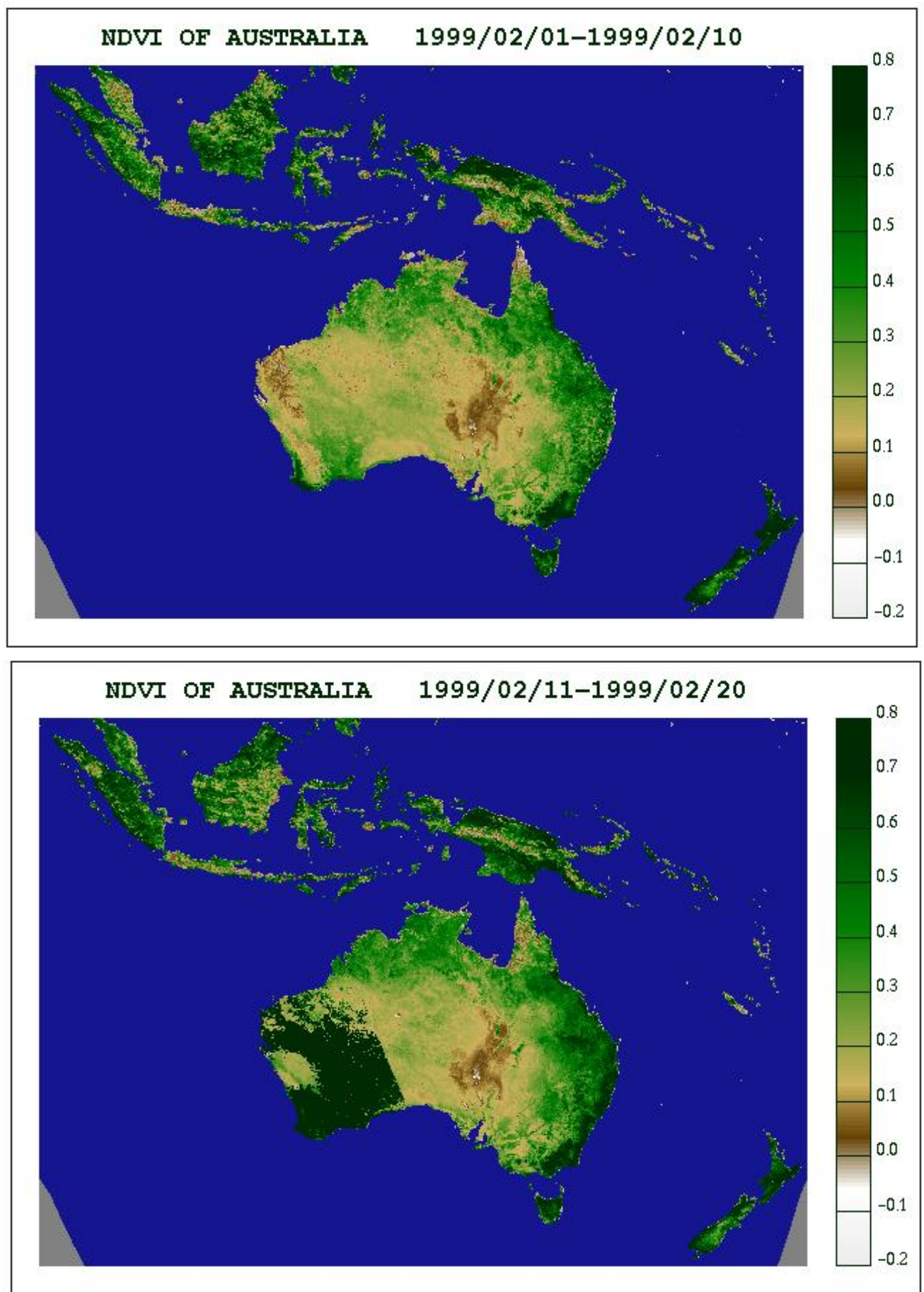


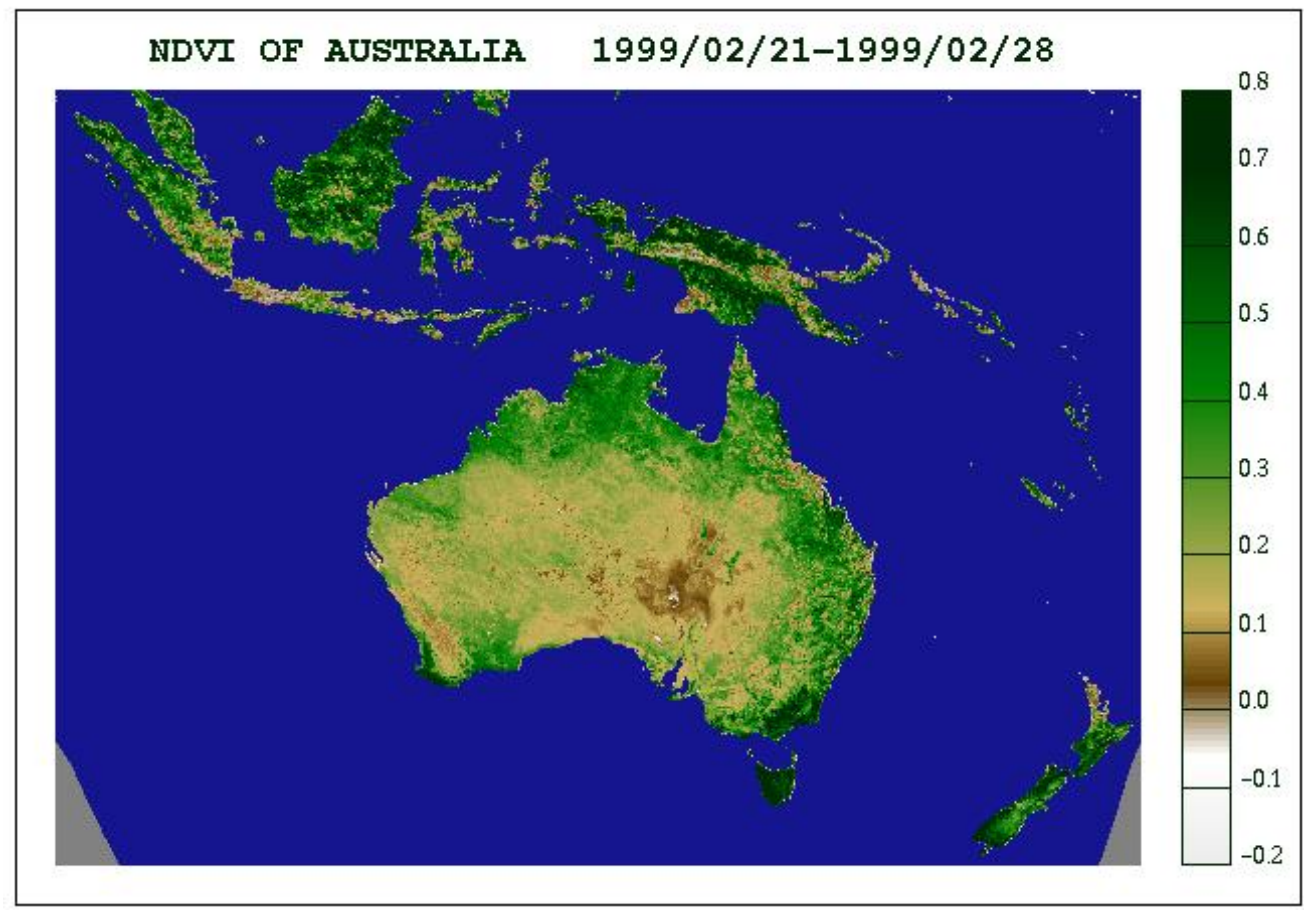

Appendix B. Foot print data of NOAA 14 obtained via NOAA's Comprehensive Large Array-data Stewardship System (CLASS).

\begin{tabular}{|c|c|c|c|}
\hline \multicolumn{4}{|c|}{ Data Set Detailed Display: } \\
\hline Inventory ID & \multicolumn{3}{|c|}{1022637} \\
\hline Datatype Name & \multicolumn{3}{|c|}{ Local Area Coverage (LAC) 1KM Level 1B } \\
\hline Orbit & \multicolumn{3}{|c|}{21288} \\
\hline$\underline{\text { Start Time }}$ & \multicolumn{3}{|c|}{ 1999-02-16 07:29:52.729 } \\
\hline End Time & \multicolumn{3}{|c|}{$1999-02-1607: 32: 39.230$} \\
\hline Quality & \multicolumn{3}{|c|}{ NBX } \\
\hline Node & \multicolumn{3}{|c|}{ Ascending } \\
\hline$\underline{\text { Sat ID }}$ & \multicolumn{3}{|c|}{ N14 } \\
\hline$\underline{\text { Dataset Name }}$ & \multicolumn{3}{|c|}{ NSS.LHRR.NJ.D99047.S0729.E0732.B2128888.WI } \\
\hline$\underline{\text { Receiving Station }}$ & \multicolumn{3}{|c|}{ Wallops Island, VA } \\
\hline$\underline{\text { Size }}$ & \multicolumn{3}{|c|}{14468} \\
\hline \multicolumn{4}{|c|}{ Overlapped Region of Geographic Search: } \\
\hline \multirow{6}{*}{\multicolumn{2}{|c|}{$\begin{array}{l}\text { Click on the thumbnail to view the full } \\
\text { image. }\end{array}$}} & \multicolumn{2}{|c|}{ Temporal (Geographic Overlap): } \\
\hline & & $\begin{array}{c}\text { Start Date: } \\
\text { 1999-02-16 } \\
07: 29: 53.499 \\
\end{array}$ & $\begin{array}{c}\text { End Date: } \\
1999-02-16 \\
07: 32: 37.974 \\
\end{array}$ \\
\hline & & $\begin{array}{l}\text { Seconds: } \\
\quad 165\end{array}$ & $\begin{array}{l}\text { Direction: } \\
\text { Ascending }\end{array}$ \\
\hline & & \multicolumn{2}{|c|}{ Spatial (Geographic Overlap): } \\
\hline & & $\begin{array}{l}\text { NW Lat,Long: } \\
-26.52,103.19\end{array}$ & $\begin{array}{c}\text { NE Lat,Long: } \\
-22,132.24\end{array}$ \\
\hline & & $\begin{array}{l}\text { SW Lat,Long: } \\
-35.95,104.34\end{array}$ & $\begin{array}{l}\text { SE Lat,Long: } \\
-31.01,136.07\end{array}$ \\
\hline
\end{tabular}


Appendix C. Time stamped Earth image from NOAA 14 passing over West Australian Coast from 07:29 to 07:32 UTC, February 16, 1999.

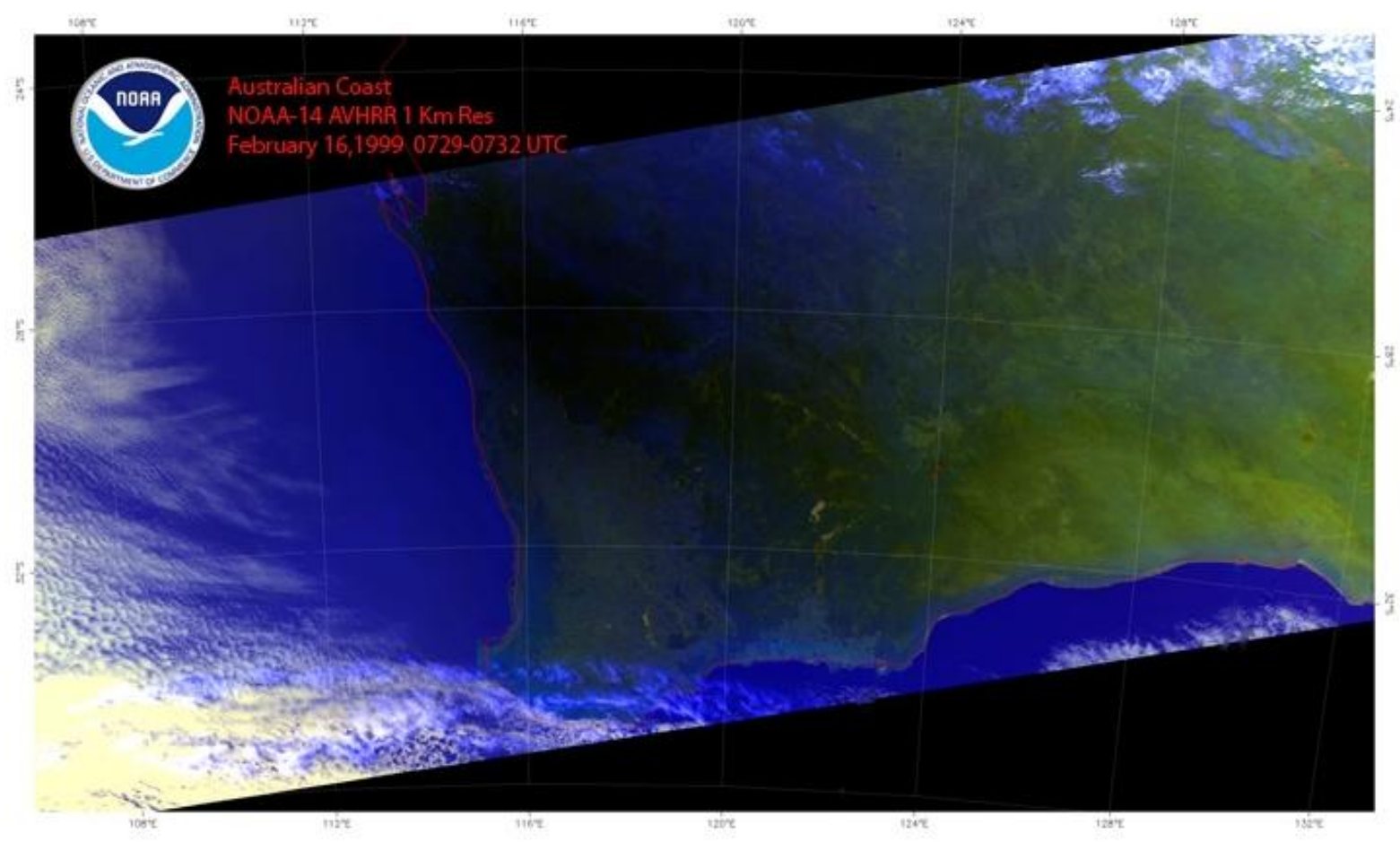

(C) 2010 by the authors; licensee MDPI, Basel, Switzerland. This article is an Open Access article distributed under the terms and conditions of the Creative Commons Attribution license (http://creativecommons.org/licenses/by/3.0/). 